\title{
DEVELOPMENT-INDUCED DISPLACEMENT IN ROMANIA: THE CASE OF ROŞIA MONTANĂ MINING PROJECT
}

\author{
Lucian VESALON ${ }^{1)^{*}}$ Remus CRETAN ${ }^{2)^{* *}}$ \\ 1) Department of Political Science, West University of Timişoara, Romania \\ ${ }^{2)}$ Department of Geography, West University of Timişoara, Romania
}

\begin{abstract}
This paper proposes a critical discussion of the population displacement processes involved in the Roşia Montană gold-mining project within the theoretical framework of development-induced displacement (DID). We begin with an overview of the geographical context of the rural community, focusing on the social and economic structure of Roşia Montană. After assessing the relocation and resettlement processes, we examine several problems related to the compensation mechanism set up by the mining company. The aim of the research is to highlight the complexity of the consequences of developmentinduced displacement and the limits of the policies of relocation and resettlement in the area.
\end{abstract}

Key Words: gold mining, development-induced displacement, relocation, resettlement, Roşia Montană, Romania

\section{Introduction}

The village of Roşia Montană is involved in one of the most debated problems in Romanian society, having also a regional and global significance. It refers to the proposed plan of displacing the local population to make room for a large-scale gold mining project. It was initiated in 1998, as a joint venture of Gabriel Resources (80.4\% shares) and the state-owned Minvest (19.3\% shares), and will use the open-pit mining process and cyanides for gold extraction (RMGC, 2012). The consequences of the project include the destruction of 1,663.89 hectares of mountain area and the displacement of the majority of the local population (RMGC 2006 , p. 1). The mining project triggered one of the largest protests against industrial development in Central and Eastern Europe.

The company began the relocation of the local population in 2002, in the absence of the government's approval for the mining project. This raises numerous sensitive problems, connected to the local and national socio-economic and political context, but also touches upon the more general practices of forced resettlement. Our paper discusses the process of population displacement in the case of Roşia Montană within the theoretical framework of development-induced displacement. The aim of the research is to examine the complexity of

*) The research for this article was supported through the grant "Trans-national network of integrated management for post-doctoral research in the field of science communication. Institutional construction (post-doctoral school) and fellowship programme (CommScie)", POSDRU/89/1.5/S/63663.

$\left.{ }^{* *}\right)$ The research for this article was supported through the project "Local partnership for the raising of doctoral school level and the putting into practice of human potential in priority domain research for Romania's post-accession stage to EU" POSDRU 21/1.5/G/38347. 
the consequences of development-induced displacement (DID) and the limits of the policies of relocation and resettlement of rural communities in the mining industry in general.

\section{Methodology}

This paper is based on the conceptual and methodological framework provided by the DID literature. We use mainly the critical assessment of policies of relocation and resettlement included in big development projects which require the displacement of the population affected by such projects. The analysis of the Roşia Montană population dynamics and structure is based on statistical data from Romanian censuses and official documents provided by the local administration and by the mining company RMGC (INSSE 2002, 2012, Varga 2002, RMGC 2006a). The discussion of compensation for the displaced persons' lost assets is based on reviewing the World Bank's policies and learning from the recent recommendations for improving the current practices in the field (Cernea 2000, De Wet 2006).

Development-induced displacement is a problem-driven approach to the phenomenon of forced migration caused by big development projects, such as dams, mines and other industrial enterprises. DID emerged both as a new academic field and as a policy response to the complexity of the social, economic, and political problems involved in this category of population migration (Cernea 1996, 2000, Turton 2006). The emergence of this field is connected to the work of Michael Cernea (1997, 2000, 2003a), a World Bank chief analyst on issues of population displacement and resettlement who had a major contribution to the adoption of the World Bank's Operational Policies and Bank Procedures (OP/BP 4.12, 2001, revised in 2004). Problem-framing in DID is typically cross-disciplinary, involving approaches from sociology, economics, geography, political science and anthropology. The study of local communities' opposition to displacement for example, is based on the study of new social movements in sociology and on the issue of cultural identities in anthropology (Oliver-Smith 2006), while the focus on poverty alleviation reflects the economic analysis in development studies (Kanbur 2003, Yan and Qian 2003).

A core issue in DID concerns the social and economic risks for the displaced persons and the strategies of addressing these risks by better policies. Population displacement has tremendously complex social consequences (Price 2009), the condition of vulnerable groups being among the most sensitive issues in the field. As Cernea explains, "all forced displacements are prone to major socioeconomic risks" (2000, p. 19). A considerable attention in the literature is given to specific categories of population affected in particular ways by displacement, such as women, elderly persons, children or ethnic groups (Newton 2008, Bisht 2009). The extreme consequence of displacement is the annihilation of community, or "social disarticulation", a phenomenon widely documented in the field (Rew, Fisher and Pandey 2006, Scudder 1996, Stein 1998, Cernea 2003a, De Wet 2006). In parallel, other authors insist more on the psychological or cultural dimension of displacement, discussing individual and collective losses which are difficult to be quantified and therefore typically ignored in resettlement programs (Fernandes 2000, Hirschon 2000).

A usual distinction in the policies of population displacement is between resettlement and relocation. The first consists in the construction of a new residential area where the displaced persons would be moved, and the latter is based on the cash compensation for properties, followed by the relocation of the former owners to a different place. This distinction is based on the World Bank's operational policies on population displacement (World Bank 2001a). The principle of compensation is of fundamental importance in the practice of relocation and resettlement. Differences in the effectiveness of compensation packages are routinely 
examined in DID literature (Morvaridi 2004, Swainson and McGregor 2008). The idea of an equitable compensation and livelihood restoration is tremendously complex from a policy perspective and also raises a number of complicated ethical questions (Penz 2002).

From a policy perspective, there are numerous sensitive problems related to the calculation of compensation packages and to the elaboration of resettlement strategies. Numerous studies led to important policy recommendations for decision-makers in resettlement projects, building on the vast experience in the field. While these recommendations aim at minimizing the social, economic, cultural and psychological risks in general, compensation remains largely related to national legal and political contexts. It is symptomatic that in the recent debates on improving resettlement policies we find calls for more "generous" compensations or for raising the awareness of gender and ethnicity, but the practice of resettlement still abounds in irregularities and questionable decisions (Rew, Fisher and Pandey 2006, p.55, Cernea 2000, p. 31, OliverSmith 2006, p. 167).

Despite significant progress in relocation and resettlement policies, the field is still undermined by unreflected ethical standards (Penz 2002) and inconsistent policy implementation. Even if many governments seem now more committed to avoiding displacement where alternative projects are possible, in reality the number of resettled populations has been constantly increasing during the last decades (UNHCR 2005). Taking into account the "inherent complexities" in DID, the consensus in the field is that, in practice, the established policies cannot provide sufficient safeguards against the complex social risks involved in resettlement (De Wet 2006, p. 181, pp. 190-193). As we will show next, the inherent limits in the policies of resettlement, combined with pre-existing social and economic vulnerabilities at Roşia Montană, increase the risks commonly associated with development-induced displacement.

\section{Study area}

Roşia Montană is located in the Apuseni Mountains, in the north-west of Alba county (Fig. 1). Of particular interest from a geographical point of view is the dispersed households, small farms and villages (Turnock 2005, pp. 37-39). There were different stages in the dynamics of population in Roşia Montană. The population of Roşia Montană was of 3,290 inhabitants in 2002 and decreased to 2,609 in 2011 (INSSE 2012). Birth rates in Roşia Montană are within the national average, but mortality rates $(13.5$ per 1,000$)$ are among the highest in Romania, due to a number of factors, such as work-related diseases and an ageing population. After the fall of communism, following the closing of mines, population decreased significantly, mainly due to the lack of local employment opportunities (Roşia Montană Town Hall 2012, p. 13). Besides these elements, the demographic downturn is especially determined by the relocation and resettlement processes, approximately 1,000 people leaving the village between 2002 and 2012.

The village had a significant ethnic and religious diversity, gradually reduced in the last decades. Ethnic and religious diversity is closely related to the history of mining in the area. During the Austro-Habsburg Empire the area was colonized with migrant workers of German and Hungarian origins (Varga 2002). There were also migrants of Jewish, Slovak and other ethnic origins. Gradually, they formed the valuable multicultural diversity of the village. If we compare data from the 2002 and 2011 censuses, it appears that the majority of ethnic groups have significantly decreased both in absolute and relative numbers (INSSE 2012). The process of ethnic homogenization began much earlier, after 1918, but in the last two decades evolved towards a significant loss of cultural diversity. The main religions present in the village are Romanian Orthodox, Roman Catholic, Greek Catholic, Protestant Unitarian, and 


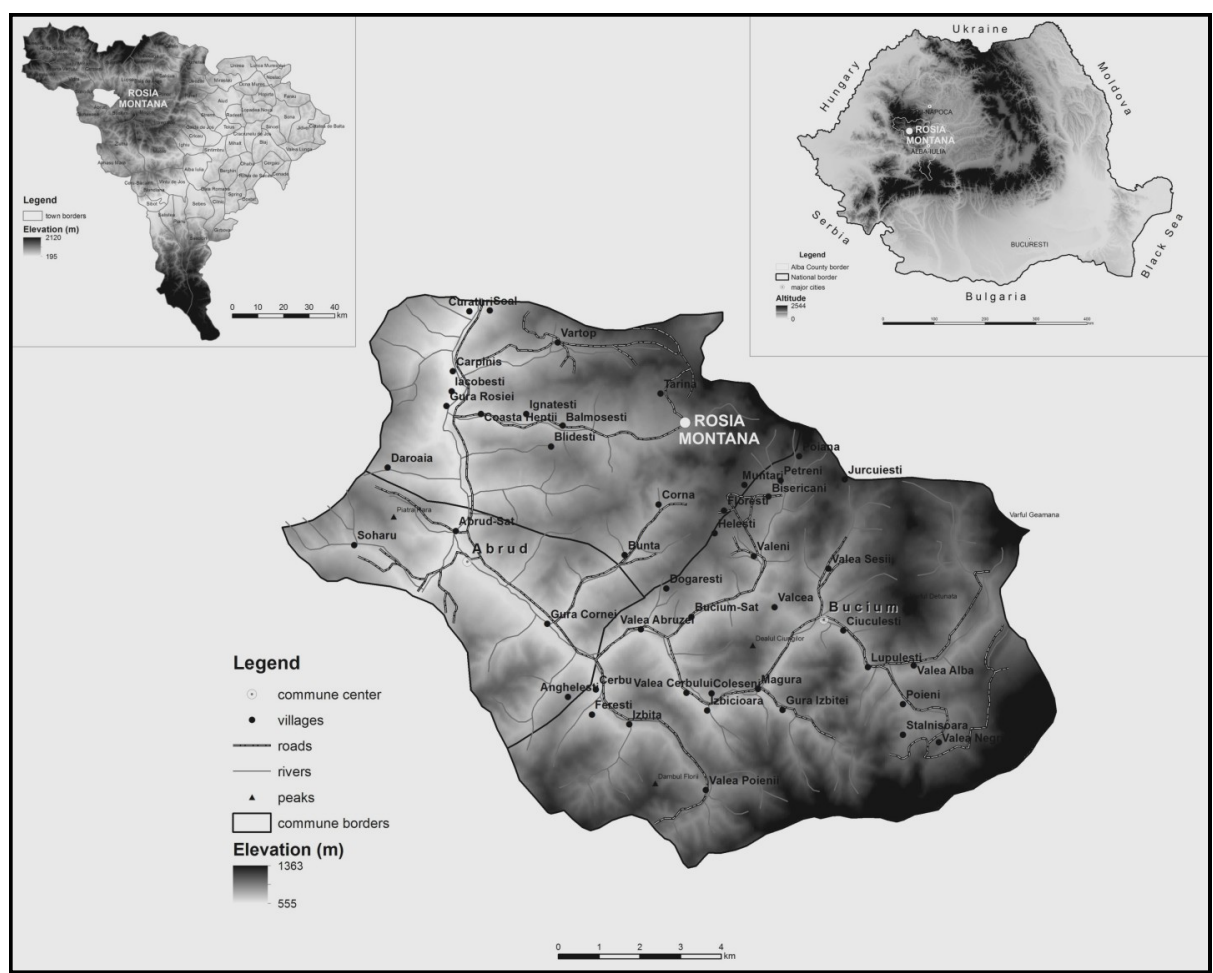

Fig.1 - The location of Roşia Montană

Neoprotestants (Varga 2002). Similarly with the ethnic trend, there was a loss of confessional diversity (INSSE 2012).

Roşia Montană was an important mining center, but the decline of mining activities led to its inclusion in the category of mono-industrial areas. Numerous aspects related to monoindustrialism in Romania were examined in the context of the socio-economic development models for post-communist societies (lanoş 2000). A sensitive issue in this context is the strategy of job creation in previously mono-industrial areas. Leaving apart the jobs offered by RMGC, there are very limited employment opportunities at Roşia Montană. In 2003, 49 people were employed in trade-related activities, and 589 persons in the mining industry, approximately 450 persons being employed by RMGC in 2012 (Olaru-Zăinescu 2006, p. 14, RMGC 2012). Unemployment in Roşia Montană is currently 15\% (INSSE 2012). Significantly, approximately $80 \%$ of the active population lives from subsistence economy. Local access to public education includes four elementary schools, secondary schools and kindergartens, attended by 330 students and served by 26 teachers (Roşia Montană Townhall 2012).

\section{Results and discussions}

The village of Roşia Montană is probably the most mentioned Romanian village in the current public debates on socio-economic development. Its popularity is connected to the mining project proposed by RMGC, which includes the relocation and resettlement of its entire population. The RMGC gold mining project was in a process of evaluation in the last ten years, 
several authorizations being released, while others being still under government supervision. The project occasioned the most important movement against an industrial development project in post-socialist Romania, motivated by the fact that it would displace the majority of the people from Roşia Montană and from the neighboring villages. Additionally, the mining project poses serious environmental threats, locally and regionally, related to a gold-extraction process involving cyanides and other high-risk technologies in process considered by numerous experts and environmentalists as designed and planned without careful consideration of risk-avoidance mechanisms.

The process of population displacement included two distinct phases. Between 2002 and 2004 there was the first stage of relocation, based on the so-called "willing-buyer/willing-seller" principle. In 2006 RMGC produced a redesigned resettlement and relocation plan, the Management of Social Impacts: Resettlement and Relocation Action Plan (MSI), which includes a comprehensive scheme for population displacement and claims to address the economic and social dimension of Roşia Montană's population. The plan reportedly complies with the World Bank policies and procedures (Operational Directive 4.30) on involuntary resettlement (RMGC 2006a, p. 1). As defined in MSI, relocation consists of the "use of compensation to purchase a property of the owner's choice", while resettlement is the "use of the compensation to purchase a new house built by RMGC on a plot located on a resettlement site developed by RMGC, or self-build a house located on such a site" (RMGC 2006a, p. 36).

In the first phase, between 2002 and 2004, the company tried to maximize the relocation procedures, RMGC making extensive property acquisitions in the area. As a result, a part of the local population left the village after selling their properties to the company. The amounts paid by the company were calculated at the market value. The estimated number of the displaced people was initially announced to be of approximately 2,000 being later recalculated at approximately 4,000 people. After 2006 displacement was carried on in two forms, which included both relocation and resettlement.

As a result, approximately 1,200 persons were displaced in the period 2002-2012. The total number of households proposed for relocation and resettlement was 794 . According to the official documentation provided by RMGC, a number of 143 houses were uninhabited, 501 families chose relocation based on the willing buyer/willing seller principle, and 150 families opted for resettlement packages (RMGC Website 2012b). A distinct category included 100 households inhabited by a single elderly occupant. The relocated population moved either to towns and cities such as Arad, Timişoara, Cluj, Oradea, Deva, Alba lulia, Abrud, Câmpeni or in the neighboring village Bucium.

Two sites were designed for resettlement. First was the quarter of Recea, in the town of Alba lulia, where 150 families moved in 2008-2009 (RMGC Website 2012b). The second resettlement site is at Piatra Alba (Roşia Montană Nouă), situated at the edge of Roşia Montană. The latter is currently under construction, but a number of 25 families have already been allocated construction lots in this neighborhood (Fig. 2). In response to the critiques regarding the destruction of the traditional way of life by resettlement, the new site is closer to the centre of Roşia Montană and promises to become a "modern - yet traditional - village" on the 60 hectares now available for the project (RMGC Website 2012b).

\section{An assessment of the relocation and resettlement process}

The research on population displacement generally shows that the main advantage of resettlement against relocation consists in the lower probability of social disarticulation 


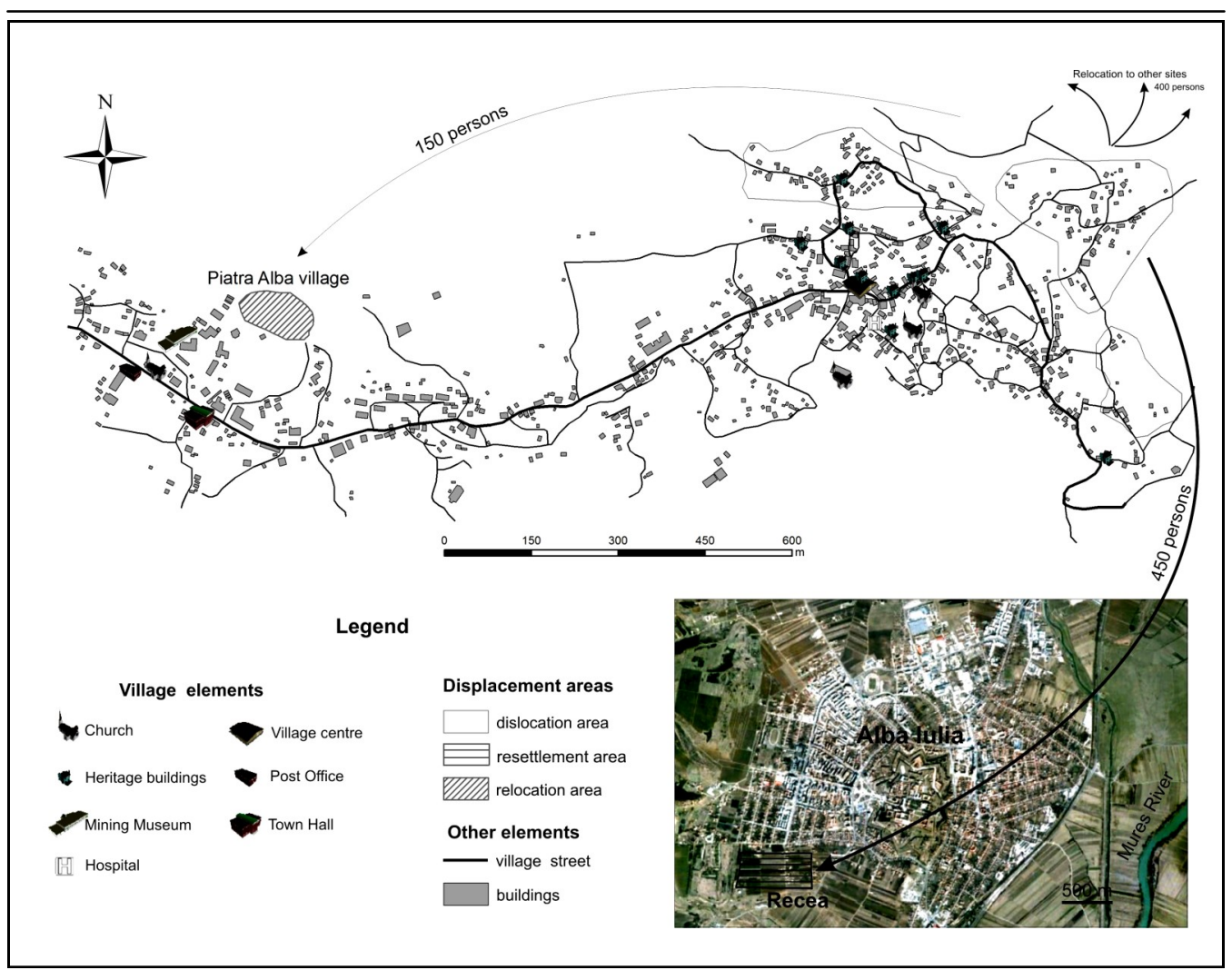

Fig. 2 - The resettlement sites for the displaced persons from Roşia Montană

occurring in the new settlement. The experience in development projects and situations of forced migration in general confirms that the strategy of resettling the entire community and to reproduce as much as possible the elements of the original locality in its new location minimize the negative social consequences (Fernandes 2000, p. 224, Hirschon 2000). Therefore, offering both resettlement and relocation as alternatives can be seen as attempts to minimize the social costs of development-induced displacement. It remains to be seen to what extent such policies address the social and economic risks for the specific case of the gold mining project, given the complex socio-economic context at Roşia Montană.

The relocation and resettlement plans were elaborated by the Canadian firm Planning Alliance, an Ontario-based company working in development projects regionally and internationally. Planning Alliance was previously involved in a contested project of relocating approximately 20,000 people in a gold mining project in Tarkwa, Ghana (Coal International/Mining \& Quarry World 2002, p. 247). From its early stages, the relocation plan sparked numerous criticisms from independent experts and NGOs. The relocation started while the mining project was pending state's approval, the mining company engaging in actions with enormous social, economic and environmental consequences before a legally defined framework for the case was established. It was then revealed that the cultural, architectural and archaeological losses would be highly significant and that relocation procedures largely disregarded these elements (Haiduc 2012, Piso 2012). Later on and in response to such criticism, RMGC redrafted the 
relocation and resettlement policies in order to include a management of the cultural and architectural heritage (RMGC 2012).

The proposed relocation and resettlement measures raise the fundamental problem of transparency and informed choice. The World Bank Operational Policies puts an emphasis on the right to be informed, to be consulted on available resettlement options and to be guaranteed "compensation at full replacement cost for losses of assets" (World Bank 2001b, paragraphs 6 and 13). The right to be informed is one of the most important principles in a democratic development and environmental decision-making process (Eckersley 2004, pp. 243-244). From a policy perspective, such a right has to be followed by detailed monitoring systems, the experience in development projects showing that the trade-off between rights and economic efficiency is often tacitly accepted and that the existing accountability mechanisms are many times inefficient (Rew, Fisher and Pandey 2006, p. 54, Hirschon 2000, p. 394).

At Roşia Montană, for more than ten years, the local community was subjected to a well coordinated pro-mining campaign, with reported intimidations and incomplete information regarding the social and environmental risks of the mining project (Simion 2012, Roth 2006, Mining Watch 2006, Egresi 2011). Such elements make a genuine free option based on access to all the relevant information problematic. Although the right to be informed is supplemented with "opportunities to participate in planning, implementing, and monitoring resettlement" (World Bank 2001b, paragraph 13), it is left to the developer to define these opportunities according to the context of the development project. In the absence of clearly defined measures in the national legal systems, this right has a lower impact in those projects not funded by the World Bank. On the other hand, the existing social and economic conditions, mainly unemployment and poverty, also contribute to limiting the actually available options for the local community. Despite such problems, voluntary resettlement remains the default option in the field: "resettlers are not forcibly displaced, but simply invited to settle new lands brought into development" (Cernea 2003, p. 42). RMGC has initially decided to focus on relocation, which is more manageable and politically less sensitive than resettlement.

A critical component in resettlement planning remains the strategy of livelihood restoration (Cernea 1996, 2000, 2003a, Koening 2006, p. 105, De Wet 2006, p. 187). A resettlement project in which people do not experience impoverishment and social disarticulation has better chances of acceptance, both by affected communities and by society in general. As we have seen, the consensus in the field is that compensation alone is not sufficient for alleviating social risks inherent in involuntary resettlement, especially impoverishment (Cernea 2003a). The policy proposals for restoring resettlers' livelihoods range from the requirement to employ resettlers in the project (De Wet 2006, pp. 194-195) to offering the resettlers a "share in the product of the project" (Fernandes 2000, pp. 210).

Employing resettlers in the project is strongly supported by experts in DID. Besides creating a sense of benefiting from the project, this policy is also likely to alleviate impoverishment. For the case of the Roşia Montană, creating jobs for resettlers in the mining project would also lower the pressure to secure land in the region to sustain the resettlers' livelihoods. This can be seen as a form of finding non-land-based livelihoods (NLBL) strategies (Rew, Fisher, Pandey 2006, pp. 61-62). The condition for such policy to be effective is to include it in the initial planning of the development project and then to offer assistance in job trainings for resettlers. This requires a significant investment, which is not yet reflected in the resettlement plan.

RMGC presents displacement as an opportunity for the project-affected population to gain better access to infrastructure, education, health services and as a chance to start new 
businesses (RMGC Website 2012b). The livelihood restoration strategy, as formulated in the $\mathrm{MSI}$, is based on a "business re-establishment package" and on a "skill enhancement fund". The first offers either a fixed compensation of 3,000 Euro, or the equivalent of a yearly turnover or "five times gross profits" plus $20 \%$ (RMGC 2006, p. 61) for the few businesses existing in the region. The second component offers English language and basic computer skills courses (RMGC 2006a, p. 62).

The land available in the new location is insufficient to meet the needs of the resettlers, being approximately ten times less than what the local population currently own and use at Roşia Montană (Toma 2006, p. 3). The monitoring and auditing mechanisms lack precision and concrete reinforcement mechanisms. A vulnerability of the project is that auditing will be done by "an independent consultant or NGO with experience in RAPP [Resettlement and Relocation Action Plan]" (RMGC 2006a, p. 72), by excluding state institutions from the process, and by making impossible in practice the independent supervision of the resettlement process. In its current form, the relocation plan does not define specific monitoring mechanisms and supervision tasks are not assigned to independent institutions. This and other similar vulnerabilities previously discussed decrease significantly the possibility of effectively implementing the international standards in involuntary resettlement.

In addition to the MSI, RMGC released a second and more complex document, the Community Sustainable Development Programme (CSDP), which seeks to address better the social and economic consequences of the mining project in the context of a broader environmental impact assessment framework (RMGC 2006b). CSDP speaks broadly about RMGC's intention to maximize social and economic welfare in the area (RMGC 2006b, p. 79). Concretely, CSDP refers to the creation of 1,200 jobs in the first phase of the project and 560 during the actual mining operations. Certainly, one can doubt that such numbers represent an "outstanding employment opportunity for the Community" (RMGC 2006b, p. 83). Apart from this reference, there are no other concrete measures mentioned in the document regarding job opportunities. In fact, RMGC seems to rely more on the idea that the mining project would generate significant economic growth in the region to provide sufficient job opportunities. The overall economic development of the region is likely to produce new jobs, but only on the condition that long-term alternatives to mining industry are designed and implemented in the region. An independent report shows that the number of new jobs created in the project is overestimated in the current project description (Bran 2003, p. 6). It is therefore important to determine to what extent the anticipated number of new jobs is realistic and if the expected economic growth generated by the project is justified by the available economic data and is sustainable after the mining closure.

\section{Compensation and Project-Affected Persons}

A critical dimension in population displacement is setting-up a compensation framework and the identification of the persons affected by the development project. RMGC defines the Project -Affected Persons (PAPs) in terms of physical (i.e. "loss of shelter and assets resulting from the acquisition of land associated with the Project that requires the affected person(s) to move to another location") or economic displacement ("loss of income streams of livelihood resulting from land acquisition or obstructed access to resources caused by the construction or operation of the Project or its facilities") (RMGC 2006a, p. 5). However, despite such an inclusive definition of PAPs, the rest of the document proves that resettlement and relocation policies are centered on commodifying land and other resources, and less on actual livelihood restoration policies. 
Compensation does not constitute a special problem in situations of voluntary migration. This solution is largely advocated in legal theory as the "free exchange" principle (Knetsch 1983) and reflected in the practice of the "willing buyer / willing seller". In DID, cases of voluntary displacement tend to be disregarded as special problems and considered the preferable alternative to involuntary resettlement (Cernea 2003a, p. 42). In real situations though, there will always be a minority refusing displacement on which compensated expropriation will be imposed and which will be involuntarily resettled. In such a case, the developer can impose the terms of the agreement on the minority (Knetsch 1983, p. 47).

The compensation measures proposed by RMGC combine and adapt the World Bank Operational Directives 4.30 and the Romanian law on expropriation for public utility works (Law 33/1994). The calculation of compensations in the RMGC relocation and resettlement project combines compensation at the market value and compensation at the replacement value. The mining company offers compensation at full replacement costs for built structures and for perennial crops (fruit trees), but proposes compensation at the market value for land and forests (RMGC 2006a, pp. 35-47). Compensation at market value is highly frequent in relocation programs, but is often criticized for increasing the risk of impoverishment, being suggested to be avoided where possible (Cernea 2003a, p. 40, Kanbur 2003, p. 33). The recommended alternative is "compensation at full replacement costs" (World Bank 2001b, para. 6 ), which has become the norm especially in those projects funded and assisted by the World Bank and other international development institutions.

It should be noted that the project does not include any compensation for the loss of access to pastures and other publicly owned land, which confirms Cernea's observation that usually the loss of access to public property is neither compensated nor properly restored (Cernea 2000, p. 29). The lots to be acquired by RMGC for resettlement being significantly smaller than the current area of Roşia Montană, it is likely that public land will be scarce and common access resources such as pastures will be inexistent. The compensation of land and forests at the market value can be therefore seen an important drawback in the proposed resettlement project.

Another questionable decision is to exclude from compensation those individuals and families who already sold their properties in the first phase of the project (RMGC 2006a, p. 47). While in itself not a legal requirement, the inclusion of relocatees from the first phase of the project in the new scheme would have been an important reparatory measure, given that information about the project was limited at that time and the value of properties was significantly lower.

Population displacement is considered acceptable if the development project brings significant economic benefits for the entire society and is thus justified in terms of public interest. In the context of development projects, individual rights (such as property rights) can be breached only in very special circumstances and where there is a public interest involved. This has to be demonstrable and the public benefits have to be significantly higher than the losses of the displaced persons and the costs of the project externalized by the company. However, democratic societies tend to avoid, where possible, the dislocation of population for development projects (De Wet 2006).

According to the public-interest perspective, interventions which violate particular individual rights are legitimate if the public interest or the global human interest is at stake. In involuntary resettlement, private property rights of the individuals are in conflict with the public interest of having, for example, cheaper access to natural resources. A situation in which the global human interest is involved can be the intervention of states to limit greenhouse gas emissions, 
interventions which interfere with individuals' economic freedoms. In general such interventions are considered morally acceptable if the public interest is evident and considered of utmost importance. In other words, population displacement would be justified "only if the encroachment has the aim of improving the national wealth and if it is proportional with the losses of the affected individuals" (Fischer and Lengauer 2003, p. 18).

In the RMGC mining project, the estimated revenues are 4 billion USD, the Romanian state's royalties were initially set up to $2 \%$, being later increased to $4 \%$, and the employment opportunities in the project reach 2,000 jobs (RMGC 2012, Gabriel Resources 2012). No comprehensive studies on the indirect economic benefits from the mining project in the region were elaborated to date, but the general opinion holds that it is unlikely that the benefits would exceed the significant social and environmental costs. The proposed revenues and royalties for the Romanian state in the Roşia Montană project were considered "unusual in the international mining industry and reminding of neocolonialist exploitation. [...] usually mining licenses stipulate revenues of 15 to 85 parts in favor of the state as in the case of oil industry" (Fischer and Lengauer 2003, pp. 18-19).

The justification of the mining project in terms of the public interest is problematic, given that the increase of national wealth is sub-optimal and potentially exceeded by the environmental and social costs of the mining operations in the region. This conclusion is contested by RMGC, their campaign to promote the Roşia Montană gold mining project being centered on demonstrating the numerous public benefits from the project, including employment and a better environmental management in the region. The debates between various expert groups, state agencies and NGOs, on one side, and RMGC on the other hand, were therefore focused on determining how the costs and benefits of the mining project should be determined and on the complexity of such calculations.

\section{Concluding remarks}

The relocation and resettlement project for Roşia Montană contains a number of elements consistent with the generally accepted policies in the field, but also significant technical problems and inconsistent policy proposals. Numerous independent experts signaled that the project is based on a superficial understanding of the economic and social context in the region of Roşia Montană (Bran et al. 2003, Toma 2006, Cernea 2003b, Haiduc 2007, Moran 2006, Olaru -Zăinescu 2006). Beyond apparently generous financial compensations, the social problems of the community remain largely unaddressed and the resettlement project offers no policy guarantees that the current social problems would not persist or that a social crisis would not occur in the new community.

In practice, the accepted policies of relocation and resettlement requires the full internalization of resettlement costs in the development project and the formulation of sound post-resettlement plans to achieve livelihood restoration at levels comparable to, or higher than those in the pre-resettlement stage. Full compensation at replacement costs has to be calculated through a flexible case-by-case mechanism (Cernea 2000). The relocation and resettlement processes were initiated by RMGC prior to the state approval of the mining project. This decision endangers the application of the proposed measures which address the social and economic risks of displacement, and especially the feasibility of livelihood restoration strategies.

Overall, the relocation and resettlement model proposed by RMGC for the people of Roşia Montană represents an uneven combination of elements from different, and often incompatible, legal and policy contexts. The project combines policy recommendations on involuntary 
resettlement elaborated by the World Bank and focused on livelihood restoration with Romanian regulation of expropriation for projects of public utility, which is framed for compensating land and built structures. The result is an eclectic policy document which sometimes makes recommendations inconsistent with the data of the mining project itself. Furthermore, the inclusion of several measures, such as land replacement or compensation at replacement value, could be compromised by poor planning and weak monitoring mechanisms.

\section{References}

BISHT, T., C. (2009) Development-induced displacement and women: the case of the Tehri Dam, India, The Asia Pacific Journal of Anthropology, 10, 4, pp.301-317.

BRAN, P. et al. (2003), The Report of the Economic Studies Academy Commission regarding the economic, financial, social, environmental, and sustainability problems of the Roşia Montană mining project ASE, Bucharest [in Romanian].

CERNEA, M. (1996), Understanding and preventing impoverishment from displacement - reflections on the state of knowledge, in McDowell, C. (ed.). Understanding impoverishment. The consequences of displacement by development, Providence, Oxford, Berghahn Books.

CERNEA, M. (1997), The Risks and reconstruction model for resettling displaced populations, World Development, 25 10, pp. 1569-1587.

CERNEA, M. (2000), Risks, safeguards, and reconstruction: a model for population displacement and resettlement, in M. Cernea and C. McDowell (eds.). Risk and Reconstruction. Experiences of Resettlers and Refugees, Washington, The World Bank, pp. 11 -55 .

CERNEA, M. (2003), For a new economics of resettlement: a sociological critique of the compensation principle, International social science journal, 55, 175, pp. 37-45.

COAL INTERNATIONAL/MINING \& QUARRY WORLD, November/December 2002.

DE WET, C. (2006), Risk, complexity and local initiative in forced resettlement outcomes, in De Wet, C. (ed.). Displacement by development. Problems, Policies and People. [Studies in Forced Migration, volume 18] New York and Oxford, Berghahn Books, pp. 180-202.

ECKERSLEY, R. (2004), The Green State. Rethinking democracy and sovereignty, Cambridge, Massachusetts, London, The MIT Press.

EGRESI, I. (2011) The curse of the gold: discourses surrounding the project of the largest pit-mine in Europe, Human Geographies 5, 2, pp. 57-68.

FERNANDES, W. (2000), From marginalization to sharing the project benefits, in M. Cernea and C. McDowell (Eds.), Risk and Reconstruction. Experiences of Resettlers and Refugees, Washington, The World Bank, Washington, pp. 205-226.

FISCHER, P., LENGAUER, A. (2003), Is Romania's environmental legislation covering the environmental impact assessment for the "Roşia Montană" Mine Project compatible with the principles and norms of European Community law?, Institute of European Law, University of Vienna, Vienna, October 2003 (Translation from the German Original by Barbara Ranzenhofer).

HAIDUC, I. (2012), The Roşia Montană mining project - between risks and benefits [Expert Position paper for the Romanian Academy] (http://www.acad.ro/Roşia_Montană/ pag_rm03_pv.htm) Accessed 20 February 2012.

HIRSCHON, R. (2000), The creation of community: well-being without wealth in an urban Greek refugee locality, in M. Cernea and C. McDowell (Eds.), Risk and Reconstruction. Experiences of Resettlers and Refugees, Washington, The World Bank, pp. 393-407.

KANBUR, R. (2003), Development economics and the compensation principle, International social science journal, 55, 175, pp. 27-35.

IANOŞ, I. (2000), Less-favoured areas and regional development in Romania, in Horvath G. (ed.) Essays in honour of Gyorgy Enyedi, Centre for Regional Studies, HAS, Pecs, pp. 176- 
191.

INSSE (2012), Press release from the National Statistics Institute (http://www.insse.ro/ cms/files/statisticilcomunicatelaltel2012lComunicatDATE PROVIZORII RPL 2011.pdf) Accessed 10 February 2012.

KNETSCH, J., L. (1983), Property rights and compensation. Compulsory acquisition and other Losses, Butterworths.

KOENING, D. (2006), Enhancing local development in displacement by development and resettlement projects in De Wet $\mathrm{C}$ ed Displacement by development. Problems, Policies and People [Studies in Forced Migration, 18], Berghahn Books, New York and Oxford, pp. 105140. Montană.

MINING WATCH (2006), Romanian villagers oppose Canadian Gold Mine at Roşia

MORAN, R., E. (2012), Review of the Roşia Montană environmental impact assessment report with a focus on water and water quality-related issues in An independent expert analysis of the Roşia Montană environmental impact assessment report (http://www.RoşiaMontană.ro/ img_upload/472936e3bca2bc61045730fbb1869240/2.raport_Moran_final.pdf), accessed 24 February 2012.

MORVARIDI, B. (2004), Resettlement, rights to development and the llisu Dam, Turkey, Development and Change, 35, 4, pp.719-741.

NEWTON, J. (2008), Displacement and development: the paradoxes of India's Tehri Dam, The Geographical Bulletin, 49, pp.19-32.

OLARU-ZĂINESCU, S. (2006), Alternative sustainable development of mining at Roşia Montană. Resource analysis and strategy elements, Alburnus Maior, Roşia Montană [in Romanian].

OLIVER-SMITH, A. (2006), Displacement, Resistance and the Critique of Development: From the Grass Roots to the Global, in De Wet, C. (ed.). Displacement by development. Problems, Policies and People, New York and Oxford, Berghahn Books [Studies in Forced Migration, volume 18].

PENZ, P. (2002), Development displacement and ethics, Forced Migration Review, 12, pp. 4-5, http://www.fmreview.org/FMRpdfs/FMR12/fmr12.1.pdf.

PISO, I. (2012), Point of view on archeological research at Roşia Montană [in Romanian] (http://www.acad.ro/Roşia_Montană/pag_rm03_pv.htm) April 4, 2012.

PRICE, Susanna (2009), Prologue: victims or partners? The social perspective in Development-Induced Displacement and Resettlement', The Asia Pacific Journal of Anthropology, 10, 4, pp. 266-282.

REW, A., FISHER, E. and PANDEY, B. (2006), Policy Practices in Displacement by development and Rehabilitation, in De Wet, C. (ed.). Displacement by development. Problems, Policies and People, [Studies in Forced Migration, volume 18], New York and Oxford: Berghahn Books. 33/1994)

ROMANIAN LAW OF EXPROPRIATION FOR PUBLIC UTILITY WORKS (LAW

ROŞIA MONTANĂ GOLD CORPORATION (2006a), Management of Social Impacts: Resettlement and Relocation Action Plan, Prepared for Roşia Montană Gold Corporation by Stantec and Frederic Giovanetti. Report available at http://www.gabrielresources.com/ documents/RRAP.pdf, accessed 22 April, 2012.

ROŞIA MONTANĂ GOLD CORPORATION (2006b), Community Sustainable Development Programme (CSDP), available at http://mmediu.ro/protectia_mediului/ rosia_montana/dvd-rosia-montana_ro_eng/Rosia\%20Montana\%20Project $/ 3 \% 20 \% \overline{20}$ Envir\% 20 and $\% 20$ Soc $\% 20$ Mngmt $\% 20$ System $\% 20$ Plans/Community $\% 20$ Sustainable $\%$ $20 \mathrm{Devel}$ opment \% $20 \mathrm{Man}$ agement \% $20 \mathrm{PIan} \% 20 \% 20 \mathrm{PI}$ an \% $20 \mathrm{~L}$ / RMP_MPL_Community_May06.log.pdf, accessed 22 April, 2012. 
ROŞIA MONTANĂ GOLD CORPORATION (2012), Roşia Montană Project: Community and property acquisition, http://en.rmgc.ro/Roșia-Montană-project/community/propertyacquisitions/state-of-play.html.

ROŞIA MONTANĂ TOWN HALL (2012), The strategic socio-economic development plan for Roşia Montană, 2008-2013, accessed at 28 February 2012) [in Romanian].

SCUDDER, T. (1996). Development-Induced Impoverishment, Resistance and RiverBasin development, in McDowell, C. (ed.). Understanding impoverishment. The consequences of Displacement by development, Providence, Oxford, Berghahn Books.

SIMION, S. (2006), Cyanide rules over Roşia Montană, Revista 22, 870 [in Romanian].

STEIN, M. (1998), The Three Gorges: the unexamined toll of displacement by development, Forced Migration Review, 1, pp. 7-9.

SWAINSON, L., McGREGOR A. (2008), Compensating for development: Orang Asli experiences of Malaysia's Sungai Selangor dam, Asia Pacific Viewpoint, 49, 2, pp. 155-67.

TURNOCK, D. (2005), Settlement history and sustainability in the Carpathians in the eighteenth and nineteenth centuries, Review of Historical Geography and Toponomastics 1, 1, pp. 31-60.

UNHCR (2005), Global Refugee Trends, Retrieved 15 May 2012 from http:// www.unhcr.org/statistics/STATISTICS/4486ceb12.pdf.

THE WORLD BANK (2001a), The World Bank Operational Manual. Bank Procedures 4.12. Involuntary Resettlement. Retrieved October 19, 2006 from http:// wbIn 0018 . worldbank. org/Institutional/Manuals/OpManual.nsf/ ebdf17733ca35635852570c9002e6d96/19036f316cafa52685256b190080b90a? OpenDocument.

THE WORLD BANK (2001b), The World Bank Operational Manual. Operational Policies 4.12. Involuntary Resettlement. Retrieved October 19, 2006 from http:// wbIn 0018 . worldbank. org/Institutional/Manuals/OpManual.nsf/ ebdf17733ca35635852570c9002e6d96/227908e400b88c4585256e8b00026e4e? OpenDocument.

TURTON, D. (2006), Who is a forced migrant? In De Wet, C. (Ed.). Displacement by development. Problems, Policies and People, [Studies in Forced Migration, volume 18], New York and Oxford, Berghahn Books, pp. 13-37.

VARGA, E. Á. (2002), Ethnic and denominational statistics in Transylvania (1850-1992) (In Hungarian).

YAN, T. and QIAN, Yi. W. (2003). Rural resettlement and land compensation in flooded areas: the Case of the Three Gorges Project, China, Asia Pacific Viewpoint, 44, 1, pp. 35-50.

Initial submission: 17.01.2012

Revised submission: 14.05 .2012

Final acceptance: 31.05 .2012

Correspondence: West University of Timişoara, Department of Geography, 4, Vasile Pârvan Blv., 300223, Timişoara, Romania

E-mail: cretan.remus@gmail.com 
